УдК 338.12

\title{
СУТНІСТЬ ТА МЕТОДИ ОЦІНКИ СТРАТЕГІЧНОГО ПОТЕНЦІАЛУ ПІДПРИЕМСТВА
}

\section{ESSENCE AND METHODS OF ASSESSMENT OF STRATEGIC POTENTIAL OF THE ENTERPRISE}

\author{
Коноплянко Денис Олегович \\ аспірант, \\ Дніпровський національний університет імені Олеся Гончара \\ ORCID: https://orcid.org/0000-0001-8780-6485
}

Konoplyanko Denis

Oles Honchar Dnipro National University

\begin{abstract}
Успіх підприємства цілком пов'язаний з розвитком стратегічного потенціалу, особливо вважаючи розвиток бізнесу України в наш час. Від нього залежать стратегічні можливості підприємства, ресурси використовуються ефективніше, можливості та резерви підприємства значно збільшуються. Стаття розглядає сутність стратегічного потенціалу та методи аналізу і дослідження стратегічного потенціалу підприємства. Розглянуто сутність категорії «стратегічний потенціал» на основі наукових праць різних науковців. Проаналізовані основні методи оцінки стратегічного потенціалу. Питання стандартизації методичних підходів стосовно оцінки та досліджень стратегічного потенціалу потребує подальшого дослідження, оскільки потенціал відіграє важливу роль у здобутті фрінансового успіху підприємства.

Ключові слова: стратегічний потенціал, стратегія, економічні ресурси, оцінка потенціалу, аналіз середовища, підприємство.
\end{abstract}

Успех предприятия целиком связан с развитием стратегического потенциала, особенно считая развитие бизнеса Украины в наше время. От него зависят стратегические возможности предприятия, ресурсы используются более эфффективно, возможности и резервы предприятия значительно увеличиваются. Статья рассматривает сущность стратегического потенциала и методы анализа и исследования стратегического потенциала предприятия. Рассмотрена сущность категории «стратегический потенциал» на основе научных трудов различных ученых. Проанализированы основные методы оценки стратегического потенциала. Вопросы стандартизации методических подходов к оценке и исследованиям стратегического потенциала требуют дальнейшего исследования, так как потенциал играет важную роль в достижении фринансового успеха предприятия.

Ключевые слова: стратегический потенциал, стратегия, экономические ресурсы, оценка потенциала, анализ среды, предприятие.

The development of market relations in the national economy requires radical changes in the system of governance at various levels, including at the micro level. His generally accepted model has focused on the processes of senior management and internal decision-making, so today's financial restructuring is hampering the inertia of managers and their focus on addressing current internal shortcomings. Sustainable development of the national economy and its integration into the European economic space correlate with the strategic development of enterprises, as a clearly defined plan of action promotes profitability and efficiency, allows to make the right management decisions taking into account foreign policy and domestic opportunities and threats. The prosperity of enterprises is entirely related to the development of strategic potential, especially considering the development of Ukrainian business today. The strategic capabilities of the enterprise depend on it, resources are used more efficiently, the capabilities and reserves of the enterprise increase significantly. Due to the fact that the strategies are implemented at all stages of enterprise development, it also contributes to the prosperity of the enterprise in the future. The issue of formation and assessment of strategic potential is important for domestic enterprises. Regular changes in the economy, crises, the development of new methods of enterprise management encourage scientists to further study the category of "strategic potential". The issue of standardization of methodological approaches to the assessment and research of strategic potential has remained unresolved. The purpose of the article is to prove the main directions of increasing the strategic potential within a modern enterprise, using methodological approaches to the formation of an assessment of the possibilities of its implementation. Effective use of strategic potential is the key to successful enterprise. 
Strategic potential plays a leading role in many enterprise processes. This is the appropriate use of resources, implementation and development of strategies, goals and directions of development. The article analyzes such concepts as composition, structure, methods of analysis and research of the strategic potential of the enterprise.

Keywords: strategic potential, strategy, economic resources, capacity assessment, environmental analysis, enterprise.

Постановка проблеми. Сталий розвиток національної економіки та її інтеграція в європейський економічний простір корелюють 3 питаннями стратегічного розвитку підприємств, оскільки чітко розроблений план діяльності сприяє росту показників прибутковості та ефрективності, дозволяє приймати правильні управлінські рішення з урахуванням зовнішньополітичних та внутрішніх можливостей та загроз.

Ефективно побудована система стратегічного управління підприємством забезпечує його фрінансову стійкість, конкурентоспроможність та ефективне функціонування на ринку. Високий рівень стратегічного мислення та управління керівника підприємства або менеджерів є одним із вирішальних фракторів розвитку та досягнення цілей діяльності. Натомість недостатнє усвідомлення значущості планування та відсутність стратегічного мислення може бути ознаками неякісного управління підприємством.

Нестабільність у бізнес-середовищі вимагає від менеджменту розв'язання проблем пристосування підприємства до тих змін, що відбуваються у зовнішньому середовищі. Зміни у середовищі, нестабільність умов, в яких веде діяльність підприємство - усе це впливає на методи прийняття управлінських рішень. Виникає потреба щодо фрормування стратегічних пріоритетів підприємства у довгостроковій перспективі.

Успіх підприємства цілком пов'язаний 3 розвитком стратегічного потенціалу, особливо вважаючи розвиток бізнесу України в наш час. Від нього залежать стратегічні можливості підприємства, ресурси використовуються ефрективніше, можливості та резерви підприємства значно збільшуються. Завдяки тому, що стратегії реалізуються на всіх етапах розвитку підприємства, це в майбутньому теж сприяє процвітанню підприємства. Питання орормування і оцінки стратегічного потенціалу важливе для вітчизняних підприємств.

Аналіз останніх досліджень і публікацій. Суть, механізм формування та методи оцінки все частіше досліджуються науковцями, оскільки стратегічний потенціал відіграє одну з основних ролей у розвитку підприємства і здобуття поставлених стратегічних цілей. Такі вчені, як В. Б. Горбань, Е. А. Лапін, Л. С. Шеховцева, О. В. Березін, О. А. Сушенко, В. А. Маркова відобразили у своїх роботах різні аспекти дослідження стратегічного потенціалу.

Виділення невирішених раніше частин загальної проблеми. Регулярні зміни в економіці, кризи, розробка нових методів управління підприємством спонукають вчених до подальшого дослідження категорії «стратегічний потенціал». Питання стандартизації методичних підходів стосовно оцінки та досліджень стратегічного потенціалу так і залишилось невирішеним.

Формулювання цілей статті. Доведення головних напрямків підвищення стратегічного потенціалу в межах сучасного підприємства, використовуючи методичні підходи до фрормування оцінки можливостей його реалізації $€$ метою статті.

Виклад основного матеріалу дослідження. Потенційні можливості значною мірою впливають на успішне фрункціонування та реалізацію стратегічних напрямків. Від них залежить якість результатів вирішення завдань та майбутніх цілей розвитку. Вони сприяють фрормуванню стратегічного потенціалу підприємства.

Стратегічний потенціал фрормується за умов реалізації стратегічних напрямків. Від них залежить якість результатів вирішення завдань та майбутніх цілей розвитку. Вони сприяють фрормуванню стратегічного потенціалу підприємства.

Стратегічний потенціал фрормується за умов реалізації стратегічних напрямків розвитку, а не лише залежить від потенційних можливостей. Весь час теоретичному і практичному аспектам стратегічного потенціалу підприємства не приділялось достатньо уваги.

Як економічна одиниця стратегічний потенціал об'єднує декілька фрункцій. Він сприяє максимальному розкриванню обсягів виробництва продукції за умов оптимального і повного використання ресурсів. Також він впливає на здатність підприємства передбачати ймовірні зміни зовнішнього довкілля та спроможність на них реагувати.

Незважаючи нате, що стратегічний потенціал $€$ предметом обговорення як вітчизняних, так і 
закордонних авторів, починаючи з 80-х років, це поняття не має однозначного трактування.

В чому ж суть поняття «стратегічний потенціал»?

За думкою О. А. Сушенко, це сукупність резервів та ресурсів, які об'єднані за стратегічними напрямами розвитку і сприяють реалізації потенційних можливостей [5].

Поняття «стратегічного потенціалу» О. В. Березін розкриває, як наявні ресурси, які сприяють виживанню підприємства серед конкурентів. Це також ресурси, які може використати підприємство [1].

$€$. В. Лапін вважає, що це не просто можливості, а ті, що є при найбільш ефрективному використанні ресурсів [3].

На думку Л. С. Шеховцевої, стратегічним потенціалом вважаються цілі виробничої системи за умови використання ії̈ ресурсів [6].

Обмежені наявні ресурси підприємства для отримання глобальних результатів, які залежать від умов навколишнього середовища - таке визначення стратегічного потенціалу доводить В. Б. Горбань [2].

В. В. Пастухова у своїй монографрії «Стратегічне управління підприємством: фрілософрія, політика, ефрективність» доводить, що стратегічний потенціал - це перш за все можливості досягнення стратегічної мети завдяки правильному використанню ресурсів [4].

Відмінностей у трактуванні поняття «стратегічний потенціал» багато, але всі науковці виділяють три основні його характеристики. Це ресурси, компетенції та цілеспрямованість.

Виділяють такі види основних ресурсів. По-перше, це технічні ресурси. До них відносяться особливості обладнання, інвентарю, матеріалів на виробництві. По-друге, це кадрові ресурси. До них належать кваліорікаційні робітники з можливістю реалізувати завдання на підприємстві. По-третє, це технологічні ресурси. Ними є зміни та інновації, наукові розробки. Далі йдуть просторові ресурси. Це територія підприємства, характер виробничих приміщень, комунікації. До ресурсів організаційної структури системи управління належать керівна система. А саме їі характер і гнучкість та проходження керівних впливів. Під інфрормаційними ресурсами розуміють оцінку інфрормації про внутрішній та зовнішній уклад підприємства 3 можливістю її розширення та підвищення ймовірності. Останнім ресурсом $\epsilon$ фрінансовий. До нього відносять стан активів та їх ліквідність, можливість отримання кредитів. Як ми бачимо, всі ресурси розкривають різноманітні можливості підприємства, які потрібні для отримання стратегічних цілей, тобто стратегічні можливості.

Для визначення суті «стратегічного потенціалу» існують такі підходи:

- Потенціал - це можливість, а не тільки ресурси для досягнення цілей. Це цільовий підхід.

- Потенціал - це об'єднання елементів, де кожен має свої задачі. Від досконалості структури залежить потенціал. Це структурнофрункціональний підхід.

- Потенціал - конкурентні переваги, завдяки яким відбувається поштовх до процвітання підприємства в наступному. Це конкурентний підхід.

Якщо проаналізувати всі підходи, поняття «стратегічний потенціал» можна визначити як сукупність наявних ресурсів та компетенцій 3 урахуванням умов зовнішнього середовища для досягнення глобальних цілей в майбутньому.

Для аналізу та оцінки стратегічного матеріалу існують різні методики. Їх існує три види.

Аналіз зовнішнього та внутрішнього середовища. До нього належать такі методи:

Метод матриці SPACE. Використовуються зовнішні фрактори. До них належать стабільність середовища, привабливість галузі. До внутрішніх фракторів відносять потенціал в фрінансах та виробництві. Всі параметри цих критеріїв оцінюють за шкалою від 0 до 6. Значущість у розрізі фрактора відображає вага, яка відповідає кожній характеристиці. Також виводиться середньозважена оцінка. В результаті розробляються стратегічні напрямки розвитку.

Аналіз SWOT. Вивчаються сильні і слабкі ринкові можливості і фрактори ризику компанії. На основі цього оцінюють фрактичне положення і стратегічні перспективи, напрями діяльності. Використовують метод зіставлення можливих комбінацій показників зовнішнього середовища і ресурсних можливостей.

PEST-аналіз означає чотири напрямки (P) - політика, (E) - економіка, (S) - суспільство, (T) - технології. Суть аналізу у виявленні та дослідженні впливу фракторів макросередовища на результати діяльності підприємства.

Конкурентоспроможність та аналіз конкурентних переваг досліджується за слідуючими методами:

1) Метод матриці БКГ. Суть методу в тому, що від конкретного виду бізнесу, організації та його положення залежить стратегічний потенціал. Важливі дві координатні осі - це темп росту і частина ринку. Формування стратегії залежить від того, в якому квадраті матриці він перебуває. 
2) «5 сил конкуренції» Портера. Проводиться дослідження для розпізнавання можливості небезпек, які можуть трапитись в любій компанії. Наприклад, наявність нових конкурентів, вплив постачальників, покупців.

3) Метод матриці Shell / DPM. Відбувається оцінка конкурентоспроможності. Це здатність використовувати переваги 3 можливостей у відповідній бізнес області, а також перспектив в діловому секторі.

4) Метод матриці GE / McKinsey. Це розширений варіант БКГ. Для оцінки потенціалу використовують показники привабливості галузі та конкурентоспроможності підприємства.

При дослідженні концепції життєвого циклу використовують такі методи:

«64 стратегеми Тарасенка». Кожна галузь підприємства та його управлінців знаходяться на різних стадіях життєвого циклу. Варіантів ймовірних станів - 64 (стратегем). Потенціал кожної з можливих комбінацій визначається за оцінкою по шкалі.

Матриця ADL. 3 декілька конкурентних положень підприємства, які складаються 3 п'яти позицій: ведуча, благополучна, сильна, міцна. Зміни в областях продаж, рух прибутку, виробництва $€$ характеристиками стадій життєвого процесу галузей. Комбінація всіх цих параметрів і формує матрицю ADL. Вона потрібна для визначення стратегічних напрямків.

Діагностика зовнішнього середовища підприємства грає важливу роль у фрормуванні стратегічного матеріалу. $€$ декілька фракто- рів, які треба враховувати при оцінюванні довгострокових перспектив розвитку. До них відносять відношення між ціною та якістю, виконання договорів та поставок у зазначений термін, обсяги виробництва, доступність кредитування.

За способом оцінки можливостей ринку виділяють індикаторні та матричні методи.

Індикаторні методи. Сукупність характеристик, які у згрупованому виді описують параметри або стан об'єкта, який досліджується називають індикатором. Після цього виробляються рекомендації для підвищення результативності об'єкта. Індикатор також складається $з$ декількох показників, які показують стан окремих елементів об'єкта. Використання індикаторних методів потрібно для оцінки конкурентоспроможності потенціалу підприємства та економіки.

Матричні методи досліджують прогрес в процесі конкуренції. Завдяки цим методам можливо оцінити конкурентоспроможність потенціалу не тільки одного підприємства, а й його конкурентів. Це сприяє розробці стратегії правильної тактики на ринку. Ці методи мають популярність серед американських консультаційних фрірм.

Метод SWOT-аналізу полягає в тому, що досліджується галузь даного підприємства. Виявляються пріоритети галузі, вони аналізуються. Це сприяє розробці різних умов та побажань до утворення стратегічного потенціалу, які знадобляться для прийняття важливих рішень в управлінні.

Таблиця 1

Приклад бальної оцінки критеріїв за методом SPACE-аналізу для підприємства

\begin{tabular}{|c|c|c|c|}
\hline Критерій & $\begin{array}{c}\text { Оцінка, } \\
\text { балів }\end{array}$ & Вага & $\begin{array}{c}\text { Зважена } \\
\text { оцінка, балів }\end{array}$ \\
\hline \multicolumn{4}{|c|}{ Фінансова сила підприємства (ФС) } \\
\hline Рентабельність інвестицій & 2 & 0,2 & 0,3 \\
\hline Динаміка прибутку & 5 & 0,5 & 0,8 \\
\hline Рівень фрінансової стійкості & 6 & 0,3 & 2,8 \\
\hline \multicolumn{3}{|l|}{ Загальна оцінка } & 3,9 \\
\hline \multicolumn{4}{|c|}{ Привабливість галузі (ПГ) } \\
\hline Рівень прибутковості галузі & 7 & 0,3 & 3,1 \\
\hline Стадія життєвого циклу галузі & 6 & 0,4 & 1,2 \\
\hline Залежність розвитку галузі від кон'юнктури & 5 & 0,3 & 2,1 \\
\hline \multicolumn{3}{|l|}{ Загальна оцінка } & 6,4 \\
\hline \multicolumn{4}{|c|}{ Стабільність галузі (СГ) } \\
\hline Стабільність прибутку & 6 & 0,4 & 4,0 \\
\hline Рівень розвитку інноваційної діяльності в галузі & 4 & 0,2 & 1,2 \\
\hline Маркетингові та рекламні можливості & 7 & 0,4 & 1,4 \\
\hline \multicolumn{3}{|l|}{ Загальна оцінка } & 6,6 \\
\hline
\end{tabular}


Для оцінки сильних та слабких сторін підприємств за групами критеріїв використовують SPACE аналіз. До груп критеріїв відносять фрінансову силу (ФС), привабливість галузі (ПГ), стабільність галузі (СГ).

Після об'єднання всіх ключових критеріїв фрормується матриця спрямованої стратегії в системі координат SPACE, а також вектор позиції підприємства. $€$ декілька типів стратегії (агресивна, конкурентна, захисна, консервативна). Тип стратегії визначають за положенням вектору. Цілі, критерії оцінювання, вплив для досягання встановлених цілей, методи, ресурси, потенціали - все це є механізмом оцінювання стратегічного потенціалу.

Висновки. Після проведеного у статті дослідження можна зробити висновок, що організації, які володіють стратегією і які впроваджують стратегічне управління, завжди мають можливість здійснювати послідовно та системно у власному підприємництві, у тому числі й у конкурентному динамічному ринковому середовищі в цілому, що збільшує мож- ливість досягнення ними поставленої мети. Тому використання вітчизняними підприємствами стратегічного керівництва в Україні i $€$ неупередженим потрібним процесом у сорері організації керівництва бізнесом, який підвищує готовність підприємницьких компаній адекватно реагувати на непередбачувані зміни та сприяє обґрунтованому, узгодженому рішенню як поточних, так і стратегічних недоліків (бо стратегічне управління у певний момент) ідентифрікує, як організація має діяти у сучасних умовах, щоб досягти бажаного завдання у майбутньому, виходячи з того, що оточення змінюватиметься). Ефрективне використання стратегічного потенціалу $\epsilon$ запорукою успішної діяльності підприємства. Стратегічний потенціал відіграє провідну роль у багатьох процесах підприємства. Це і доцільне використання ресурсів, реалізація і розробка стратегії, цілей та напрямків розвитку. В статті розібрані такі поняття як склад, структура, методи аналізу і дослідження стратегічного потенціалу підприємства.

\section{СПИСОК ВИКОРИСТАНИХ ДЖЕРЕЛ:}

1. Березін О.В. Завдання та механізми оптимізації структури виробничого потенціалу підприємства. Вісник національного ун-ту водного господарства та природокористування : зб. наук. пр. Економіка. 2019. № 4(40). C. 20-27.

2. Горбань В.Б. Управління стратегічним потенціалом машинобудівного підприємства. URL: http://intkonf.org/ gorban-vb-upravlinnya-strategichnim-potentsialom-mashinobudivnogo-pidpriemstva/

3. Лапин Е.В. Экономический потенциал предприятия как экономическая категория. Науковий вісник Чернівецького торговельно-економічного інституту КНТЕУ. 2002. Вип. 2. С. 380-385.

4. Пастухова В.В. Стратегічне управління підприємством: фрілософрія, політика, есрективність : монографія. Київ : КНТЕУ, 2002.

5. Сущенко О.А. Формування стратегічного потенціалу підприємства : дис. канд. психол. наук. Луганськ, 2002.

6. Шеховцева Л.С. Стратегический менеджмент : учебное пособие. Калининград : Изд-во РГУ им. И. Канта, 2006.

\section{REFERENCES:}

1. Berezin O.V. (2019) Zavdannya ta mehanizm optimizacii strukturi potencialu pidriemstva [Tasks and mechanisms for optimizing the structure of the production potential of the enterprise]. Visnik Nacionalnogo universitetu vodnogospodarsta ta prirodocoristuvannya. Economica, 4(40), 20-28. (in Ukrainian)

2. Gorban V.B. Upravlinnya strategicnim potencialom mashinobudivnogo pidriemstva [Management of strategic potential of a machine-building enterprise]. Retrieved from: http://intkonf.org/gorban-vb-upravlinnya-strategichnim-potentsialom-mashinobudivnogo-pidpriemstva/ (in Ukrainian)

3. Lapin E.V. (2002) Economiceskii potencial predriyatiya kak ekonomiceskaya categoriya [The economic potential of the enterprise as an economic category]. Naucnii visnik Cherniveckogo torgovelnogo economicnogo institutu KNTEU, 2(22), 380-385. (in Ukrainian)

4. Pastuhova V.V. (2002) Strategichne upravlinnya pidriemstvom: filoshophia, politica, efectivnis [Strategic management of the enterprise: philosophy, policy, efficiency]. Kyiv: KNTEU. (in Ukrainian)

5. Susenko O.A. (2002) Formuvannya strategicnogo potencialu pidriemstva [Formation of strategic potential of the enterprise]. Candidate's thesis. Lugansk. (in Ukrainian)

6. Shehovsteva L.S. (2006) Strategicheskii menegment: uchebnoe posobie [Strategic management: study guide]. Kaliningrad: Isd-vo RGU im. I. Kanta. (in Russian) 